\title{
Nutrition and sow prolificacy
}

\author{
F. X. Aherne and R. N. Kirkwood \\ Department of Animal Science, University of Alberta, Edmonton, Alberta, Canada T6G 2P5
}

\begin{abstract}
Summary. Prolificacy has been defined as the number of viable piglets produced per year or per breeding lifetime. Prolificacy is influenced by age at first successful mating, ovulation rate and embryo survival at each mating, number of live born, viable pigs and the sow's ability to be successfully remated at regular intervals.

It is concluded that under normal conditions of feeding and management nutrition will have a minimal influence on gilt prolificacy. However, to gain the advantages of a slightly younger age at puberty, maximal ovulation rate and an adequate fat cover (if only to ensure against subsequent poor management), gilts should be fed ad libitum up to the time of mating. Long-term performance is best served by minimizing fluctuations in live weight and fat reserves, so avoiding extremes of body condition and subsequent poor performance. This is achieved by small controlled increases in sow body weight during pregnancy and feeding to appetite for restricted periods each day during lactation. Assuming the sow has not achieved a very poor condition during lactation, feeding level during pregnancy will have little effect on numbers of piglets born, and only a limited influence on piglet birthweights. The conclusion that piglet birth weights will be influenced more by total pregnancy feed intake than pattern of feed distribution is unchallenged. Lactation feed intake is shown to have marked effects on the post-weaning performance, low-level feeding leading to an extension of the remating interval and possibly increasing embryo mortality.

No benefit of high-level feeding after weaning is demonstrable, except possibly in primiparous sows or sows having suffered an extreme loss of liveweight and body condition during the previous lactation.
\end{abstract}

\section{Introduction}

Over the past 15 years there have been numerous reviews of sow nutrition as it affects reproductive performance (MacPherson, Elsley \& Smart, 1969; Elsley \& MacPherson, 1972; Elsley, 1973; ARC, 1981; Cole, 1982). For many of the experiments reviewed, the criticism of Elsley (1973) "that many nutritional experiments with sows are not undertaken with sufficient accuracy, replication or duration to allow us to detect even a $10 \%$ difference in sow productivity or to evaluate long term effects on breeding regularity" still apply today. In addition to the above criticism, much of the earlier work dealt with the effects of nutrition within a discrete area of the breeding cycle (i.e. pregnancy, lactation or the post-weaning period) and as such only demonstrated direct effects. What is becoming increasingly apparent is that nutrition may have indirect effects, the most notable being the influence of feed intake and weight gain in gestation on feed intake and weight change in lactation, and the influence of feed intake and weight and body composition changes in lactation on the post-weaning and early gestation performance. In addition to these reviews there have been regular estimates of the nutrient requirements of breeding sows by the National Academy of Sciences, National Research Council of the USA (NAS-NRC, 1959, 1964, 1968, 1973, 1979) and by the Agricultural Research Council $(1967,1981)$ in the United Kingdom. However, Whittemore (1983) suggested that nutrient requirements cannot be stated in fixed terms but that 
nutrients are required at levels to satisfy a targeted response in the animal consistent with the animal's genetic potential and its environment. ARC (1981) has attempted to do this, although Cole \& Harker (1983) consider that the upper target gain for pregnant sows of $40 \mathrm{~kg}$ suggested by the ARC (1981) is excessive, while the data of Whittemore, Franklin \& Pearce (1980) would suggest that the lower suggested target gain of $20 \mathrm{~kg}$ is too low.

In recent years it has been suggested that the long-term reproduction of the sow is best served by minimizing weight and fat loss in lactation (Cole, 1982). Such a strategy would require only a minimal restoration of weight in the following pregnancy which would be beneficial since the greater the feed intake and weight gain in pregnancy the greater the weight loss in lactation (Salmon-Legagneur \& Rerat, 1962; O’Grady, 1980).

A final criticism of the literature to date is that white in many instances a physiological effect on the female reproductive system has been attributed to the influence of nutrition no attempt has been made to ascertain the nature of this nutritional effect. Of particular note is the practice of flushing to increase ovulation rate. This phenomenon was described by Coop (1966), but its mechanism of action remains to be determined almost 20 years later.

For the purposes of this review, prolificacy is defined as number of viable piglets produced per sow, either per year or per breeding lifetime. For simplicity, this review is structured to take account of the individual phases of the sow's breeding cycle while stressing that nutrition in one period may exert its influence in another.

\section{Gilt nutrition}

Gilts are likely to constitute $30-40 \%$ of the breeding females of a herd, and therefore factors affecting gilt reproductive performance will have a significant impact on overall herd prolificacy. These factors are age at successful mating, ovulation rate at the oestrus of mating, first litter size and the ability to be successfully remated.

\section{Age at puberty}

Age at successful mating is largely dependent on age at puberty. Therefore, to maximize productivity it would seem appropriate that management and nutritional regimens be employed to induce puberty as early as possible. There have been several reviews on the effect of nutrition on puberty onset (Anderson \& Melampy, 1972; Brooks \& Cole, 1974; Den Hartog \& van Kempen, 1980 ), and a common conclusion is that while very severe feed or energy restriction $(50 \%$ of ad-libitum levels) will delay the onset of puberty, less severe restriction (60-70\% of ad-libitum levels) leads to variable results; restriction delayed puberty in 2 trials, advanced puberty in 10 and had no effect in 15 (Den Hartog \& van Kempen, 1980). That 50\% feed or energy restriction delays puberty is not unexpected since such a severe restriction is likely to slow all somatic growth and as reproductive development has a lower priority for dietary energy than does general growth (Gunther, cited by Den Hartog \& van Kempen, 1980), puberty will be delayed. Restricting energy intake delayed puberty by an average of 16 days in 9 experiments, yet hastened puberty by an average of 11 days in 5 others (Anderson \& Melampy, 1972). Den Hartog \& van Kempen (1980) reported that in restricted-fed gilts puberty is delayed by 9 days (Table 1), a result similar in magnitude to the results of Anderson \& Melampy (1972). According to the data of Legault \& Dagorn (1973) the 9-day delay noted by Den Hartog \& van Kempen (1980) represents a reduction in sow productivity of about 0.2 pigs per year. Therefore, unless more substantial changes in age at puberty are found, changes in prolificacy will be less than impressive. However, the data of Etienne, Camous \& Cuvillier (1983) indicate that large differences in age at puberty may appear if a restriction $(33 \%)$ is imposed from an early age (Table 2 ). This may indicate a critical period during 
Table 1. Influence of energy intake of gilts during rearing on age and weight at puberty (from Den Hartog \& van

Kempen, 1980)

\begin{tabular}{lcc}
\hline & Low & High \\
\hline Number of trials & 22 & 14 \\
Mean starting age (days) & $86 \cdot 7$ & $85 \cdot 8$ \\
Mean starting weight (kg) & $36 \cdot 2$ & $34 \cdot 8$ \\
Mean energy intake (MJ ME/day) & $22 \cdot 3$ & $34 \cdot 4$ \\
Age at puberty (days) & 211 & 202 \\
Weight at puberiy (kg) & 80 & 99 \\
\hline
\end{tabular}

Table 2. Influence of feed restriction of gilts (up to $60 \mathrm{~kg}$, and between $60 \mathrm{~kg}$ and puberty) or ad-libitum feeding on age and weight at puberty (from Etienne et al., 1983)

\begin{tabular}{lccc}
\hline $\begin{array}{l}\text { Fecding level } \\
\text { Period of restriction }\end{array}$ & $\begin{array}{c}\text { Restricted } \\
28-60 \mathrm{~kg}\end{array}$ & $\begin{array}{c}\text { Restricted } \\
60 \mathrm{~kg} \text { to puberty }\end{array}$ & Ad-libitum \\
\hline Age at puberty (days) & 255.8 & 225.5 & 232.2 \\
Weight at puberty (kg) & 123.7 & 11.0 & 124.3 \\
\hline
\end{tabular}

growth when a moderately severe restriction will retard development, but once beyond this period only a very severe (e.g. $50 \%$ ) restriction will delay puberty.

There is general agreement in the literature that limited protein restriction during the rearing period will not influence puberty attainment. In only one of 10 experiments reviewed by Den Hartog \& van Kempen (1980) did protein restriction have a favourable effect on age at puberty. However, severe restriction will cause a delay of puberty onset (Jones \& Maxwell, 1974; Wahlstrom \& Libal, 1977). There is also evidence that the amino acid balance of the protein supplied may influence puberty attainment (Fowler \& Robertson, 1954; Friend, 1973).

It is suggested that modern diets which meet recognized standards of energy and protein content (including amino acid balance) have allowed gilts to express their potential in terms of age at puberty and only limited further improvements can be expected. Indeed, environmental factors and husbandry practices are far more likely to influence age at puberty than is nutrition.

\section{Ovulation rate}

The major constraint on first litter size is ovulation rate (King \& Williams, 1984c). Delaying mating until second or third oestrus allows the use of short-term high-level feeding to increase ovulation rate. The subject of fiushing has been extensively reviewed previously (Anderson \& Melampy, 1972; Brooks \& Cole, 1974; Den Hartog \& van Kempen, 1980). It is firmly established that increasing feed or energy intake before mating will increase ovulation rate (Table 3), and the optimum period of increased intake appears to be in excess of 11 days. Variable results are obtained when gilts are given increased energy intake on the day before or on the day of mating, whilst no effect is noted if it is given on the day after mating.

What still remains to be determined is whether flushing increases ovulation rate beyond that which would be normally expected, or reverses a nutritional inhibition due to previous low-level feeding. That the latter is a possibility is suggested by the average daily energy intakes of high and low energy groups reviewed by Den Hartog \& van Kempen (1980) (41.1 and 22.5 MJ metabolizable energy (ME)/day respectively). The energy intake for the restricted gilts is far below what would normally be fed in commercial practice. Anderson \& Melampy (1972) suggested that optimal 
Table 3. Influence of premating dietary energy intake on ovulation rate in sows (adapted from Den Hartog \& van Kempen, 1980; data in parentheses are from Anderson \& Melampy, 1972)

\begin{tabular}{|c|c|c|c|c|}
\hline & \multicolumn{4}{|c|}{ Period of feeding } \\
\hline & \multicolumn{2}{|c|}{ Rearing } & \multicolumn{2}{|c|}{ Oestrous cycle } \\
\hline & Low & High & Low & High \\
\hline $\begin{array}{l}\text { Number of trials } \\
\text { Energy intake (MJ ME/day) } \\
\text { Ovulation rate }\end{array}$ & $\begin{array}{l}21 \quad(7) \\
21.2(17.6) \\
.11 .8(13.8)\end{array}$ & $\begin{array}{l}21(7) \\
33 \cdot 8(36 \cdot 9) \\
613 \cdot 2(15 \cdot 4)\end{array}$ & $\begin{array}{l}30(24) \\
22.5(24 \cdot 1) \\
=11.8(11.6)\end{array}$ & $\begin{array}{l}36(24) \\
41 \cdot 1(42 \cdot 1) \\
b_{1} \cdot 7 \cdot 7(13 \cdot 4)\end{array}$ \\
\hline
\end{tabular}

Within feeding period, means with different letters differ significantly $(P<0.00 \mathrm{l})$.

ovulation rate is obtained by about a $25 \mathrm{MJ} \mathrm{ME}$ /day increase in energy intake. Thus, for gilts previously fed only $17.6 \mathrm{MJ} \mathrm{ME}$ /day (Table 3), the final daily energy intake would be $42.6 \mathrm{MJ} \mathrm{ME}$ which is close to that recommended by the NRC (1979) for a $100 \mathrm{~kg}$ gilt.

\section{Protein level}

At protein levels between 12.5 and $16 \%$, source or level of protein appears to have little effect on ovulation rate (Fowler \& Robertson, 1954; Zimmerman, Peo \& Hudman, 1967). Over a short period ( 1 cycle) protein deprivation has little effect on ovulation rate. However, prolonged feeding (4-6 cycles) of a protein-free diet led to a significant reduction in ovulation rate (McGillivray et al., 1964).

\section{Conception rate}

Conception rate will influence the interval between puberty and effective service. There is no clear evidence in the literature regarding the influence of nutrition on conception rate in gilts. The results of 26 experiments employing high and low feed intakes up to puberty, or during the oestrous cycle, reviewed by Den Hartog \& van Kempen (1980), gave differences in conception rates of between 80.5 and $88 \%$, which were not significant.

\section{Embryo survival}

High-level feeding during rearing or in the premating period is associated with an increased embryo mortality (Table 4). The reasons for this are unclear, although the data indicate that gilts having high energy intakes had an increased ovulation rate and evidence reviewed by Anderson \&

Table 4. Influence of feeding level on embryo survival in gilts (adapted from Den Hartog \& van Kempen, 1980)

\begin{tabular}{lcccc}
\hline Period & $\begin{array}{c}\text { No. of } \\
\text { trials }\end{array}$ & $\begin{array}{c}\text { Energy intake } \\
\text { (MJ ME/day) }\end{array}$ & $\begin{array}{c}\text { No. of } \\
\text { embryos }\end{array}$ & $\begin{array}{c}\text { Embryo } \\
\text { survival (\%) }\end{array}$ \\
\hline Prepubertal & 19 & $35 \cdot 7$ & 9.8 & $69 \cdot 7^{* *}$ \\
& 46 & 22.8 & 10.0 & $77 \cdot 5$ \\
Premating & 36 & 38.5 & 10.1 & $73 \cdot 2^{*}$ \\
& 31 & 21.6 & $9 \cdot 7$ & 78.3 \\
\hline
\end{tabular}

$\because * P<0.01 ; \bullet P<0.04$. 
Melampy (1972) and Den Hartog \& van Kempen (1980) suggests that an increased ovulation rate will lead to an increased embryo mortality and therefore only a small, if any, increase in final litter size.

\section{Long-term performance}

Currently, a major issue regarding the replacement gilt is the influence of level of backfat at selection or mating on the short- and long-term prolificacy of the sow. Modern gilts are mated younger, lighter and with less body fat reserves than those of a decade ago (Table 5) and there has been concern that this would lead to an increase in culling rates, especially after the production of the first litter.

Table 5. The influence of selection on gilt backfat measurements at $90 \mathrm{~kg}$ liveweight (data from Alberta R.O.P.)

\begin{tabular}{|c|c|c|c|}
\hline \multirow[b]{2}{*}{ Year } & \multicolumn{3}{|c|}{ Gilts home tested (1973-1984) } \\
\hline & $\begin{array}{l}\text { No. } \\
\text { tested }\end{array}$ & $\begin{array}{c}\text { Average } \\
\text { backfal } \\
(\mathrm{mm})\end{array}$ & $\begin{array}{c}\text { Average } \\
\text { age at } 90 \mathrm{~kg} \\
\text { (days) }\end{array}$ \\
\hline 1973 & 1,568 & $19 \cdot 6$ & 191 \\
\hline 1974 & 1,579 & $19 \cdot 1$ & 188 \\
\hline 1975 & 2.411 & 18.5 & 179 \\
\hline 1976 & 3,159 & 17.8 & 174 \\
\hline 1977 & 4,390 & $17 \cdot 4$ & 172 \\
\hline 1978 & 7,790 & 16.8 & 177 \\
\hline 1979 & 9,988 & $16 \cdot 0$ & 177 \\
\hline 1980 & 9,664 & $15 \cdot 7$ & 174 \\
\hline 1981 & 9,778 & 15.8 & 174 \\
\hline 1982 & 10,990 & $15 \cdot 2$ & 172 \\
\hline 1983 & 11,809 & 14.8 & 167 \\
\hline 1984 & 12,004 & $15 \cdot 4$ & 171 \\
\hline
\end{tabular}

The amount of body fat in gilts at mating may range from 16 to $37 \mathrm{~kg}$ (Elsley \& Gilchrist Shirlaw, 1976). However, there is evidence that initial body composition differences in gilts are greatly reduced by the time the sow has farrowed her second litter, primarily due to the fatter gilts loosing more liveweight and backfat during the first lactation (Table 6). In terms of prolificacy it has also been shown that the total number of pigs produced after 3 litters is independent of initial oestrus at mating (and presumably backfat depth) of replacement gilts (Table 7). It therefore appears that selection for leaner gilts, and mating at relatively young ages has no adverse effect on long-term performance, provided nutrition and management are satisfactory. However, an as yet undetermined minimum fat cover is required as the successful reproduction and breeding of very lean gilts allows little margin for error in nutritional management over the entire breeding cycle. It is therefore, recommended that genetically lean gilts that are being mated before they reach $120 \mathrm{~kg}$ liveweight be fed ad libitum during the growing-finishing period (20-100 kg liveweight) and up to the time they are mated. Such a feeding regimen will maximize body weight and body condition and may result in increased ovulation rate and litter size at farrowing.

\section{Pregnancy}

If feeding regimen is to influence prolificacy it may do so during the course of a single gestation by influencing embryo and fetal survival, number of pigs born or viability of liveborn pigs. 
Table 6. Changes in midbackfat depth (BF) for conventional and early mated gilts (from Brooks, 1982)

\begin{tabular}{lcc}
\hline & Early mated & Conventionally mated \\
\hline Mean mating age (days) & 198 & 237 \\
BF post partum (litter 1) & 18.8 & 25.0 \\
BF at weaning (litter 1) & 16.8 & 18.2 \\
BF at remating & 18.2 & 18.0 \\
Parity 2 & 14.6 & 15.3 \\
Parity 3 & 14.0 & 15.1 \\
Parity 4 & \\
\hline
\end{tabular}

Table 7. The effect of oestrus of mating on performance of sows over 3 parities (from MacPherson et al., 1977)

\begin{tabular}{lrrr}
\hline & \multicolumn{3}{c}{ Oestrus of mating } \\
\cline { 2 - 4 } & \multicolumn{1}{c}{1} & \multicolumn{1}{c}{2} & \multicolumn{1}{c}{3} \\
\hline Weight at 1st mating (kg) & 88.1 & 98.2 & 115.1 \\
Weight at 4th mating (kg) & 165.5 & 168.9 & 165.8 \\
Pigs weaned (1st litter) & 7.8 & 8.3 & 8.6 \\
Pigs weaned (litters 1-3) & 26.5 & 26.4 & 26.9 \\
\hline
\end{tabular}

\section{Feed and energy intake}

The feed and energy requirements of the pregnant sow will depend on her live weight, her target body weight gain during pregnancy and other management and environmental parameters. From an analysis of 20 experiments Elsley (1973) calculated that feed intake in pregnancy was highly correlated with live weight gain of sows $(0.71)$, reasonably correlated with piglet birth weight $(0.46)$ but poorly correlated with litter size $(0 \cdot 14)$. Most studies since that time have confirmed that wide variations in feed intake do not significantly influence litter size (ARC, 1981). Indeed, Whittemore, Taylor, Hillyer, Wilson \& Stamataris (1984) reported that gestation feed intakes of between 1.7 and $2.3 \mathrm{~kg} /$ day maintained for 5 parities had no significant effect on total numbers born. The majority of experiments have also demonstrated that although there may be a progressive increase in piglet birth weights with increasing sow feed or energy intake during pregnancy (Fig. 1), the response above $25 \mathrm{MJ}$ digestible energy (DE)/day was seldom significant (Libal \& Wahlstrom, 1977; Henry \& Etienne, 1978; ARC, 1981), the major effect being seen with maternal weight gain. However, levels of energy below $20 \mathrm{MJ} \mathrm{DE} /$ day have generally reduced fetal weights significantly (Close, Noblet \& Heavens, 1984). It is well established that the greater the weight gain and level of backfat deposition during gestation, the greater will be the weight and backfat depletion during the subsequent lactation (Brooks \& Smith, 1980; Seerley \& Ewan, 1983) due at least in part to a reduced appetite in lactation (Salmon-Legagneur \& Rerat, 1962). It is therefore suggested that the minimum requirement of digestible energy for a pregnant sow of $140 \mathrm{~kg}$ and having a $25 \mathrm{~kg}$ net body gain should be $25 \mathrm{MJ} /$ day (Cole, 1982; Seerley \& Ewan, 1983).

\section{Protein intake}

Although sow'weight gain will respond to increased protein intake up to levels of $300 \mathrm{~g} /$ day in gestation, no improvement in reproductive performance is apparent beyond a daily intake of approximately $140 \mathrm{~g}$ supplying 8-10 g lysine, 7-8 g threonine and $1.5 \mathrm{~g}$ tryptophan (O'Grady, 1980; 


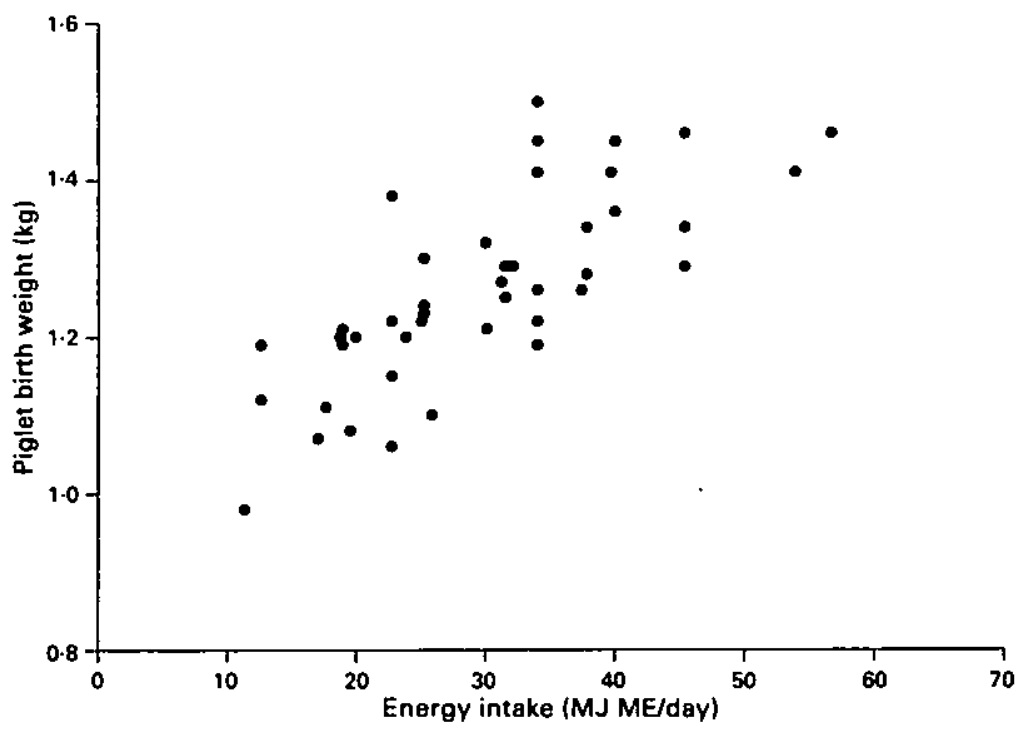

Fig. 1. Influence of energy intake of the sow during gestation on piglet birthweight (summary of 14 experiments).

ARC, 1981; Cole, 1982). For a sow weighing $140 \mathrm{~kg}$ with a target net weight gain of ' $25 \mathrm{~kg}$ the diet should supply $230 \mathrm{~g}$ protein per day. In a review of the literature, Speer (1982) stated that feeding very low protein levels $(0 \cdot 5-2 \cdot 0 \%)$, protein-free diets or even periods of complete inanition do not seem to affect adversely embryo or fetal development or litter size but may reduce birth weight. It is apparent that nutrition during the course of a single pregnancy has, at most, only a limited direct influence on reproductive performance. However, severe protein and/or energy restriction.during both gestation and lactation, especially if maintained over several parities, will significantly reduce the number of sows exhibiting oestrus after weaning, number of days to oestrus and ovulation rate (Holden, Lucas, Speer \& Hays, 1968; Svajgr et al., 1972; Pike \& Boaz, 1972; Hovell \& MacPherson, 1977).

\section{Pattern of feed intake}

In addition to feed levels over the entire pregnancy, interest has also been expressed in the influence of short-term nutrition within the gestation period. Although high-energy intakes before mating increase ovulation rate, continuation of these dietary regimens in early pregnancy may decrease embryo survival (Table 8). However, a recent study by Toplis, Ginesi \& Wrathall (1983) failed to confirm an effect of high energy intake on early embryo survival. These authors suggested that in trials in which a detrimental effect of nutrition on early embryo survival has been demonstrated, the experimental animals tended to be gilts and in trials in which no effect is noted, older animals are more usual. They further suggested that since the various nutritional regimens were usually implemented at or very soon after mating an increase in ovulation rate may have occurred and increased ovulation rates are associated with increased embryo mortality. A further indication that this may be the case is that in the trials in which Den Hartog \& van Kempen (1980) noted an effect of nutrition on embryo survival, actual numbers of embryos present were very similar (Table 8). It is customary to evaluate embryo mortality 20-30 days post coitum but this may lead to false conclusions. Levels of embryo mortality of $18 \cdot 8-33 \%$ were reported by Etienne et al. (1983) for gilts on various prepubertal feeding regimens. However, these differences were reversed for fetal mortality (assessed at 105 days of gestation) which lead to no difference in actual fetal numbers. In 
Table 8. Influence of energy level $(\mathrm{L}=$ low; $\mathrm{H}=$ high) during rearing, the oestrous cycle and after mating on ovulation rate, number of embryos and embryonic survival in gilts (from Den Hartog \& van Kempen, 1980)

\begin{tabular}{lclc}
\hline & \multicolumn{3}{c}{ Sequence of treatments } \\
\cline { 2 - 4 } & LLL & LHL & HHH \\
\hline $\begin{array}{l}\text { No. of trials } \\
\begin{array}{l}\text { No. of ova shed } \\
\text { (calculated) }\end{array}\end{array}$ & 26 & 14 & 15 \\
$\begin{array}{l}\text { No. of embryos } \\
\text { Embryonic survival } \\
(\%)\end{array}$ & 9.6 & 13.9 & 14.0 \\
\hline
\end{tabular}

Within rows, means followed by different letters differ significantly $(P<0 \cdot 05)$.

Table 9. The effects of feed level in gestation on plasma progesterone levels and embryo survival in sows (from Dyck et al., 1980)

\begin{tabular}{lcc}
\hline Feed level & $\begin{array}{c}\text { Embryo } \\
(\%)\end{array}$ & $\begin{array}{c}\text { Mean } \\
\text { progesterone } \\
(\mathrm{ng} / \mathrm{ml})\end{array}$ \\
\hline Low & 82.8 & 16.7 \\
Medium & 78.6 & 13.8 \\
High & 71.9 & 11.8 \\
\hline
\end{tabular}

trials in which embryo survival is decreased, the effect may be mediated by a reduction in plasma progesterone, since both increased feed or protein in early pregnancy has been shown to influence plasma progesterone (Jordan \& Swanson, 1979; Dyck, Palmer \& Simaraks, 1980; Table 9).

Theoretically, the nutrient requirements of sows increase with advance in pregnancy, following the pattern of fetal development. Fetal weight is doubled over the last month of pregnancy, especially in the last 10 days, which is the period of most rapid fetal growth. Therefore, there has been considerable interest in the influence of pattern of gestation feeding on piglet birth weights. Cromwell et al. (1982), using 848 sows, increased daily sow feed intake by $1.36 \mathrm{~kg}$ for the last 23 days of pregnancy and noted a significant increase $(50 \mathrm{~g})$ in piglet birth weights. However, the biological significance of this result is contentious since Hillyer \& Phillips (1980), using 304 sows, obtained very similar weight gains which were not significant (Table 10). In both trials, total feed intakes were very different between treatment groups. Elsley et al. (1971) fed sows the same total feed in various patterns and found no effect on piglet birth weights and this suggested that the pattern of feed intake during pregnancy is less important than total amount fed. It has been stated by Cole (1982) that if any benefit is to be gained from increasing feed levels in late gestation, it will only be to increase birth weight when this might have been expected to be low. Moser \& Lewis (1980) and Seerley (1984) have reviewed the data dealing with the influence of increased dietary energy density by adding fat and have concluded that supplementing the diet of the periparturient sow with fat (optimum level $7.5 \%$ ) increases the fat content of colostrum and milk, and survival of smail $(<0.9 \mathrm{~kg})$ piglets is also improved. In general, the addition of lipid to the diet of sows in late gestation has not increased the fat or glycogen content of the newborn pig (Seerley, 1984). The feeding of fat to sows in late gestation and during lactation has been reported to shorten the interval between weaning and oestrus (Seerley, 1984). 
Table 10. Influence of increased feed level in late gestation on sow and piglet performance (data from Cromwell et al. (1982) and Hillyer \& Phillips, 1980)

\begin{tabular}{lcc}
\hline & \multicolumn{2}{c}{ Feed level } \\
\cline { 2 - 3 } & Basal & High \\
\hline $\begin{array}{l}\text { Sow gestation weight } \\
\text { change (kg) }\end{array}$ & 39.8 & 48.9 \\
Piglet birth weight (kg) & $1.41(1.36)$ & $1.46(1.39)$ \\
\hline
\end{tabular}

\section{Lactation}

The energy and protein requirements of the lactating sow will depend on the weight of the sow, her milk yield and its composition and her target change in weight during lactation. For a sow weighing $165 \mathrm{~kg}$ at parturition, producing an average of $6.2 \mathrm{~kg}$ milk and losing $6.5 \mathrm{~kg}$ weight throughout a 42-day lactation, a daily intake of $75 \mathrm{MJ} \mathrm{DE}$ and $750 \mathrm{~g}$ protein per day should suffice. It is well established that levels of feed, energy or protein intake will affect sow body weight changes as well as milk yield and composition (ARC, 1981; Cole, 1982). However, as our definition of prolificacy is the number of viable pigs produced either per year or per breeding lifetime, nutrient intake during lactation will have no direct effect on sow prolificacy. However, lactation feeding strategies may have considerable indirect effects, i.e. influencing the productivity of the sow after weaning. Indirect effects of lactation feeding regimen on prolificacy will be expressed in terms of the length of the remating interval, ovulation rate, conception rate, embryo mortality and subsequent litter size.

\section{Remating interval}

Although early work with sows failed to demonstrate an influence of lactation energy intake on the weaning to remating interval (O'Grady, Elsley, MacPherson \& McDonald, 1973), the sows in these trials probably had considerable initial backfat reserves and the level of energy restriction was not particularly severe (50-80 MJ DE/day). More recent investigations have firmly established that sows loosing excessive amounts of live weight or body condition will have extended remating intervals and an increased incidence of anoestrus (King, Williams \& Barker, 1982, 1984; Reese et al., 1982a, b; Reese, Peo \& Lewis, 1984; King \& Williams, 1984a, b; Hughes, Henry \& Pickard, 1984).

What remains undefined is the level of weight or condition loss below which an extension in the remating interval will occur and the level of dietary energy intake required to prevent this extension. The results of Reese et al. (1982a, b, 1984), King \& Williams (1984a) and King et al. (1984) have been summarized in Table 11. The results have been partitioned according to whether the energy intake was higher or lower than $50 \mathrm{MJ} \mathrm{DE} /$ day. Values for low energy intake varied between 26 (King \& Williams, 1984a, b) and 33.6 (Reese et al., 1982a, b, 1984) MJ DE/day, and it can be seen that increasing the energy intake to around $50 \mathrm{MJ} \mathrm{DE} /$ day produced a considerable improvement in the remating interval. However, increasing energy intake beyond $50 \mathrm{MJ} \mathrm{DE} /$ day provided little or no further improvements (Reese et al., 1982a). It should be noted that in all trials, restrictions were maintained for only one lactation. Reese $e t$ al. (1984) subdivided their low-energy group into those that did and those that did not return to oestrus and noted that the lactation weight loss and post-weaning weight gain were very similar, indicating that weight change per se had little or no influence on the time taken to achieve oestrus. However, they did note that the lactation backfat loss was higher in those sows that remained anoestrous $(P=0.1)$ and the calculated percentage body fat was lower $(P<0.05)$. This is an indication of a physiological function for adipose tissue, a suggestion more fully discussed by Kirkwood \& Aherne (1985). Some muscle 
Table 11. Influence of lactation energy intake on days to oestrus in sows

\begin{tabular}{lccc}
\hline $\begin{array}{l}\text { Energy intake } \\
\text { (MJ DE/day) }\end{array}$ & $\begin{array}{c}\text { \% in oestrus } \\
\text { by Day } 8\end{array}$ & $\begin{array}{c}\% \text { in oestrus } \\
\text { by Day 14 }\end{array}$ & $\begin{array}{c}\% \text { anoestrous } \\
\text { on Day 21 }\end{array}$ \\
\hline$>50$ & $86.9(7)$ & $95.0(5)$ & $1.2(5)$ \\
$<50$ & $55.0(6)$ & $64.8(4)$ & $20.1(5)$ \\
\hline
\end{tabular}

Numbers in parentheses refer to the number of trials.

wasting occurred in the energy-restricted sows as judged by serum creatinine concentrations but this was considered by Reese et al. (1984) not to be related to delayed expression of oestrus.

The adverse influence of condition loss on the duration of the remating interval is not limited to pigs as a similar situation has been documented for cattle (Rutter \& Randel, 1984). The physiological mechanism(s) whereby lactation condition change affects the remating interval are unknown. However, studies with cattle have described a negative correlation between basal plasma luteinizing hormone (LH) during the remating interval and weight loss (Rutter \& Randel, 1984) and a similar situation may be occurring in pigs (Nelssen et al., 1984). The reasons for this lower LH level and its possible consequences remain to be determined.

\section{Ovulation rate}

Hardy \& Lodge (1969) reported that ovulation rate at the first post-weaning oestrus was significantly influenced by live weight changes in the previous lactation. Brooks (1982) suggested that gilts that become catabolic during lactation may remain so after weaning and as a consequence have reduced ovulation rates. However, other studies have failed to detect an effect of weight loss in lactation on ovulation rate (Pike \& Boaz, 1972; King et al., 1982; King \& Williams, 1984a, b; Hughes et al., 1984). The adverse affects of large liveweight changes on conception rate reported by Hardy \& Lodge (1969) have not been confirmed by others (Reese et al., 1982b; King et al., 1984; King \& Williams, 1984a) and may be a result of poor detection of oestrus in sows having uncharacteristic weaning to remating intervals.

\section{Embryo survival}

While there is general agreement that low-level feeding in lactation adversely influences the weaning to remating interval, whilst not affecting subsequent ovulation rate, the influence of lactation feed level on subsequent embryo survival is not clear. Thus, King \& Williams (1984a, b) reported no influence of low lactation dietary energy or protein intakes on embryo survival, while others do note an adverse effect of low-level feeding (King et al., 1984; Hughes et al., 1984; Table 12). It is clear that insufficient work has been done in this area. An obvious question is whether a minimum backfat level must be achieved, rather than a minimum backfact depletion, before embryo survival is compromised (i.e. will poor lactation nutrition only adversely affect those sows already relatively thin). If condition loss in lactation is to affect embryo survival, the mechanism of action remains unclear. It may be a similar situation to that experienced following early weaning where an increase in embryo mortality is also seen. Following short lactations, the preovulatory release of LH at natural or oestrogen-induced oestrus is significantly reduced (Kirkwood, Lapwood, Smith \& Anderson, 1984a; Kirkwood, Lapwood, Smith, Moller \& Garrick, 1984b) and it has been suggested that this may influence the quality of luteinization of the corpora lutea with possible implications for progesterone (or some other luteal product) secretion and thus embryo survival. That LH (or some other pituitary product) may influence luteinization is indicated by the results of du Mesnil du Buisson \& Leglis (1963) who noted that hypophysectomy of cyclic gilts prevented the corpora lutea 
from achieving their full weight (and presumably full activity) even though pig corpora lutea are considered to require no luteotrophic support.

It is known that live weight change in lactation will influence live weight and backfat change in the post-weaning period (Henry, Pickard \& Hughes, 1984; Hughes et al., 1984; Table 13). It has also been documented that, in sheep, plane of nutrition can have a marked influence on hepatic blood flow (Bensadoun \& Reid, 1962). In sows having excessive weight and fat losses in lactation, it is possible that an increased hepatic blood flow after weaning is increasing the metabolic clearance rate of plasma progesterone. Indeed, Hughes et al. (1984) reported a lower plasma progesterone profile during early pregnancy and an increased metabolic clearance rate of plasma progesterone (P. E. Hughes, personal communication) in sows that received a flow feed level in the previous lactation, together with a concomitant increase in embryo mortality.

Table 12. The effects of lactation feed level on postweaning reproductive performance of sows (after Hughes et al. (1984) and S. Baidoo, R. N. Kirkwood, F. X. Aherne \& A. P. Sather, unpublished)

\begin{tabular}{lcc}
\hline & \multicolumn{2}{c}{ Lactation feed level (kg/day) } \\
\cline { 2 - 3 } & 3 & 7 \\
\hline Remating interval & 8.0 & $5 \cdot 5$ \\
Ovulation rate & 19.0 & 18.5 \\
Embryo survival (\%) & 63.4 & $75 \cdot 3$ \\
\hline
\end{tabular}

Table 13. Influence of lactation feed level on fiveweight and backfat changes in the sow (summary of 7 experiments)

\begin{tabular}{lrc}
\hline & \multicolumn{2}{c}{ Lactation feed level } \\
\cline { 2 - 3 } & Low & High \\
\hline Liveweight loss in lactation $(\mathrm{kg})$ & 27.9 & 6.9 \\
$\begin{array}{l}\text { Backfat loss in lactation }(\mathrm{kg}) \\
\text { Liveweight change }\end{array}$ & 6.0 & 1.4 \\
$\begin{array}{l}\text { weaning-remating }(\mathrm{kg}) \\
\text { Backfat change } \\
\text { weaning-remating }(\mathrm{mm})\end{array}$ & +2.1 & -6.9 \\
\hline
\end{tabular}

\section{After weaning}

The major objectives of nutrition during this period are to shorten the interval to effective mating, synchronize the onset of oestrus and maximize the ovulation and conception rates. Previous recommendations have included a 'drying off' period for at least $24 \mathrm{~h}$ after weaning during which the sow receives no food or water. It has been suggested that this is an effective means of shortening and synchronizing the interval to oestrus (MacLean, 1969). More recent evidence indicates no beneficial value of this practice (Allrich, Tilton, Johnson, Slanger \& Marchello, 1979; Tribble \& Orr, 1982) and it may even be detrimental with some management systems (Allrich et al., 1979).

\section{Remating interval}

Of greater interest is the influence of post-weaning plane of nutrition on the remating interval of 
sows. Increasing the level of feeding after weaning has been reported to shorten the interval to service in primiparous sows (Brooks \& Cole, 1972), to increase the numbers exhibiting oestrus within 10 days of weaning (Brooks \& Cole, 1972; Fahmy \& Dufour, 1976) and increase the synchronization of oestrus (Dyck, 1972). Other reports failed to confirm an effect of nutrition on the length of the weaning to service interval (Dyck, 1972, 1974; Brooks, Cole, Rowlinson, Croxson \& Luscombe, 1975; Fahmy \& Dufour, 1976; Den Hartog \& van der Steen, 1981; Tribble \& Orr, 1982). It is possible that the result of Brooks \& Cole (1972) was due to the use of gilts in their study which may respond differently from multiparous sows to post-weaning feed intake. However, Den Hartog $\&$ van der Steen (1981) also used primiparous sows and observed no response to variations in post-weaning feed intake. Brooks et al. (1975) stated that all animals in their trial were subjected to an excellent standard of management and overall there was no loss of body weight during lactation. Whilst not measured, these authors estimated that in their earlier work (Brooks \& Cole, 1972) the primiparous sows lost about $20 \mathrm{~kg}$ live weight during lactation. It therefore seems possible that a further indirect nutritional effect exists, i.e. lactation feed level (and thus weight change pattern) may affect the response of sows to the post-weaning feed level. There is therefore a requirement for information on the influence of post-weaning feed level on the reproductive performance of sows which have had different lactation nutritional histories. It seems possible that high energy intakes after weaning may benefit those sows destined for a prolonged remating interval but generally, in a well managed herd, post-weaning nutrition will not affect the time taken to reach oestrus.

\section{Ovulation rate}

The available information on the influence of post-weaning nutrition on ovulation rate at the first oestrus and subsequent litter size is contentious. The normal remating interval for a sow is variable but may be as low as 4-5 days and as such appears to correspond to the follicular phase of a normal oestrous cycle. Therefore it may be expected that sows will respond to nutritional changes in this period in a similar manner to gilts. However, there is little evidence to support a claim for high level feeding during the remating interval affecting either the ovulation rate or subsequent litter size of sows. This may in part be due to the relatively short time span involved since Dyck (1974) reported that increasing feed level will not affect the first post-weaning ovulation rate, but does increase ovulation rate at the second post-weaning oestrus (Table 14). Lodge \& Hardy (1968) did report an increased litter size in flushed sows $(9 \mathrm{vs} 10.8)$ although this may be the result of control sows having a low mean litter size. The flushing therefore seems to have brought a low litter size back to 'normal' rather than cause an increase above what was to be expected. Indeed, with larger litter sizes in the control groups, various authors have failed to confirm a stimulatory effect of increased feed intake on ovulation rate (Fahmy \& Dufour, 1976; Tribble \& Orr, 1982).

\section{Conception rate}

Increasing post-weaning feed levels for primiparous sows has been reported to improve

Table 14. Effect of nutrition on ovulation rate of sows at first or second oestrus after weaning (data from Dyck, 1974)

\begin{tabular}{lcc}
\hline & \multicolumn{2}{c}{ Oestrous period } \\
\cline { 2 - 3 } Feed level $(\mathrm{kg})$ & 1 & 2 \\
\hline 1.82 & 11.6 & 11.9 \\
2.72 & 10.2 & 12.5 \\
\hline
\end{tabular}


conception rates (Brooks \& Cole, 1972), although this is not confirmed by results from older sows (Dyck, 1972; Brooks et al., 1975; Fahmy \& Dufour, 1976; Tribble \& Orr, 1982). However, the possibility of an interaction between lactation and post-weaning feed levels remains to be adequately investigated. It is concluded that level of feeding in the remating interval is unlikely to improve reproductive performance unless it is to reverse a reduction in performance due to poor nutrition management in lactation (Pike \& Boaz, 1972).

\section{Conclusions and speculations}

This review further supports the already well accepted conclusion that severe under or overfeeding of the breeding female will adversely affect her reproductive performance. However, the gilt and sow can tolerate a moderate nutritional insult for several parities without any significant effect on prolificacy, although maternal weight gain and body composition will be affected. It has been suggested that the long-term reproductive performance of sows is best served by a feeding regimen that will conserve body fat reserves.

It is not clear how excessive weight or fat loss affect reproductive performance. The influence of changes in body composition on steroid metabolism has been reviewed previously (Kirkwood \& Aherne, 1985). Briefly, it is suggested that adipose tissue can metabolize androgens to oestrogens and the potency of the end product (e.g. oestradiol, oestrone, oestriol or catechol oestrogens) will be influenced by the level of fat reserves. Also, adiposity may influence the relative amounts of free and bound steroid, possibly by the changes in sex steroid-binding globulin (the existence or not of SSBG in pigs remains undetermined) or a competition for carrier protein (e.g. albumin) binding sites with elevated concentrations of plasma fatty acids ( $F$. Evans, personal communication). Nutritional regimen may also alter rates of steroid clearance by increasing hepatic blood flow and/or hepatic mixed function oxidase activity. This mechanism has been used to explain the flushing effect on ovulation rate (Kirkwood \& Aherne, 1985). It may also be implicated in trials in which high levels of feeding in early gestation have been associated with an increased embryo mortality. Such a situation may become apparent when low levels of lactation feed are causing a positive weight change from weaning through early gestation, further accentuated by increased levels of feeding.

Changes in oestrogen metabolism may influence pituitary function. Indeed, an association between body composition and plasma gonadotrophin levels has been demonstrated (see Kirkwood \& Aherne, 1985). Low-level feeding for extended periods will depress ovulation rate and it is suggested that flushing does not result in an increased number of ova shed, but merely normalizes the ovulation rate. Pituitary LH stores have been shown to be lower in gilts previously fed very low levels of energy. Also, it has been shown that long-term malnutrition of sows leads to disruption of the anterior pituitary basophil cells and thus presumably a reduction in gonadotrophin production and release (Wadman \& Holness, 1973).

Much of the above is speculation, but since the existence of reproduction-nutrition interactions has been firmly established, it is now time that the mechanisms involved were investigated.

\section{References}

Agricultural Research Council, ARC (1967, 1981) The nutrient requirements of pigs. ARC, London.

Allrich, R.D., Tilton, J.E., Johnson, J.N., Slanger, W.D. \& Marchello, M.J. (1979) Effect of lactation length and fasting on various reproductive phenomena of sows. J. Anim. Sci. 48, 359-362.

Anderson, L.L. \& Melampy, R.M. (1972) Factors affecting ovulation rate in the pig. In Pig Production, pp. 329-366. Ed. D. J. A. Cole. Butterworths, London.

Bensadoun, A. \& Reid, J.T. (1962) Estimation of rate of portal blood flow in ruminants: effects of feeding, fasting and anesthesia. J. Dairy Sci. 45, 540-543.

Brooks, P.H. (I982) The gilt for breeding and for meat. In Control of Pig Reproduction, pp. 211-224. Eds D. J. A. Cole \& G. R. Foxcroft. Butterworths, London. 
Brooks, P.H. \& Cole, D.J.A. (1972) Studies in sow reproduction. 1. The effect of nutrition between weaning and remating on the reproductive performance of primiparous sows. Anim. Prod. 15, 259-264.

Brooks, P.H. \& Cole, D.J.A. (1974) The effect of nutrition during the growing period and the oestrous cycle on the reproductive performance of the pig. Livest. Prod. Sci. 1, 7-20.

Brooks, P.H. \& Smith, D.A. (1980) The effect of mating age on the reproductive performance, food utilization and live weight change of the female pig. Livest. Prod. Sci. 7, 67-78.

Brooks, P.H., Cole, D.J.A., Rowlinson, P., Croxson, V.J. \& Luscombe, J.R. (1975) Studies in sow reproduction. 3. The effect of nutrition between weaning and remating on the reproductive performance of multiparous sows. Anim. Prod. 20, 407-412.

Close, W.H., Noblet, J. \& Heavens, R.P. (1984) The partition of body-weight gain in the pregnant sow. Livest. Prod. Sci. 11, 517-527.

Cole, D.J.A. (1982) Nutrition and reproduction. In Control of Pig Reproduction. pp. 603-619. Eds D. J. A. Cole \& G. R. Foxcroft. Butterworths, London.

Cole, D.J.A. \& Harker, A.J. (1983) European approaches to piglet and sow feeding during lactation. Proc. 4 th West. Nutr. Conf., Saskatoon, pp. $138-162$.

Coop, I.E. (1966) Effect of flushing on reproductive performance of ewes. J. agric. Sci.. Camb. 67, 305-323.

Cromwell, G.L., Prince, T.J., Combs, G.E., Maxwell, C.V., Knabe, D.A. \& Orr, D.E. (1982) Effects of additional feed during late gestation on reproductive performance of sows. A cooperative study. J. Anim. Sci. 55, Suppl. 1, p. 268. Abstr.

Den Hartog, L.A. \& van der Steen, H.A.M. (1981) Reproductive traits in primiparous sows in relation to feeding level. Neth. J. agric. Sci. 29, 285-296.

Den Hartog, L.A. \& van Kempen, G.J.M. (1980) Relation between nutrition and fertility in pigs. Neth. J. agric. Sci. 28, 211-227.

du Mesnil du Buisson, F. \& Leglis, P.C. (1963) Effet de l'hypophysectomie sur les corps jaunes de la truie. Resultats preliminaries. C. r. hebd. Séanc. Acad. Sci., Paris D. 257, 261-263.

Dyck, G.W. (1972) Effects of post weaning level of feeding on return to oestrus in sows. Can. J. Anim. Sci. $52,570-572$.

Dyck, G.W. (1974) The effect of stage of pregnancy, mating at the first or second estrus after weaning and level of feeding on fetal survival in sows. Can. J. Anim. Sci. 54, 277-285.

Dyck, G.W., Palmer, W.M. \& Simaraks, S. (1980) Progesterone and luteinizing hormone concentrations in serum of pregnant gilts on different levels of feed consumption. Can. J. Anim. Sci. 60, $877-884$.

Elsley, F.W.H. (1973) Nutrition of the female pig during pregnancy and lactation. Paper presented to Pig Commission, E.A.A.P., Vienna.

Elsley, F.W.H. \& Gilchrist Shirlaw, D.W. (1976) Aspects of the energy nutrition of sows. Proc. 27th Ann. Meeting EAAP Zurich. Paper PI, 14 pp.

Elsley, F.W.H. \& MacPherson, R.M. (1972) Protein and amino acid requirements in pregnancy and lactation.
In Pig Production, pp.417-434. Ed. D. J. A. Cole. Butterworths, London.

Elsley, F.W.H., Bathurst, E.V.J., Bracewell, A.G., Cunningham, J.M.M., Dent, J.B., Dodsworth, T.L., MacPherson, R.M. \& Walker, N. (1971) The effect of pattern of feed in pregnancy upon sow productivity. Anim. Prod. 13, 257-269.

Etienne, M., Camous, S. \& Cuvillier, A. (1983) Effect of feed restrictions during growth on puberty and reproductive performance in gilts. Reprod. Nutr. Develop. 23, 309-319.

Fahmy, M.H. \& Dufour, J.J. (1976) Effects of post weaning stress and feeding management on return to oestrus and reproductive traits during early pregnancy in swine. Anim. Prod. 23, 103-110.

Fowler, S.H. \& Robertson, E.L. (I954) Some effects of source of protein and antibiotic on reproductive performance in gilts. J. Anim. Sci. 13, 949-954.

Friend, D.W. (1973) Influence of dietary amino acids on the age of puberty of Yorkshire gilts. J. Anim. Sci. 37, $70 !-707$.

Hardy, B. \& Lodge, G.A. (1969) The effect of body condition on ovulation rate in the sow. Anim. Prod. II, 505-510.

Henry, R.W., Pickard, D.W. \& Hughes, P.E. (1984) The effects of lactation length and food level on the subsequent reproductive performance in the sow. Anim. Prod. 38, 527, Abstr.

Henry, Y. \& Etienne, M. (1978) Alimentation energetique du porc. Journées Rech. porc. en France $10,119-165$.

Hillyer, G.M. \& Phillips, P. (1980) The effect of increasing feed level to sows and gilts in late pregnancy on subsequent litter size, litter weight and maternal body weight change. Anim. Prod. 30, 469, Abstr.

Holden, P.J., Lucas, E.W., Speer, V.C. \& Hays, V.W. (1968) Effect of protein level during pregnancy and lactation on reproductive performance in swine. $J$. Anim. Sci. 27, 1587-1590.

Hovell, F.D.DeB. \& MacPherson, R.M. (1977) Thin sows. 1. Observations on the fecundity of sows when underfed for several parities. J. agric. Sci., Camb. 89, 513-522.

Hughes, P.E., Henry, R.W. \& Pickard, D.W. (1984) The effects of lactation food level on subsequent ovulation rate and early embryonic survival in the sow. Anim. Prod., 38, 527, Abstr.

Jones, R.D. \& Maxwell, C.V. (1974) Effect of protein level on growth, nitrogen balance and reproductive performance in gilts. J. Anim. Sci. 39, 1067-1072.

Jordan, E.R. \& Swanson, L.V. (1979) Serum progesterone and luteinizing hormone in dairy cattle fed varying levels of crude protein. J. Anim. Sci. 48, 1154-1158.

King, R.H. \& Williams, I.H. (1984a) The effect of nutrition on the reproductive performance of first litter sows. 1. Feeding level during lactation and between weaning and mating. Anim. Prod. 38, 24l-247.

King, R.H. \& Williams, I.H. (1984b) The effect of nutrition on the reproductive performance of first litter sows. 2. Protein and energy intakes during lactation. Anim. Prod. 38, 249-256.

King, R.H. \& Williams, I.H. (1984c) The influence of ovulation rate on subsequent litter size in sows. Theriogenology 21, 677-680. 
King, R.H., Williams, I.H. \& Barker, I. (1982) Reproductive performance of first litter sows in an intensive piggery. Proc. Aust. Soc. Anim. Prod. 14, 557-560.

King, R.H., Williams, 1.H. \& Barker, I. (1984) The effect of diet during lactation on the reproductive performance of first litter sows. Proc. Aust. Soc. Anim. Prod. 15, 412-415.

Kirkwood, R.N. \& Aherne, F.X. (1985) Energy intake, body composition and reproductive performance of the gilt. J. Anim. Sci. 1518-1529.

Kirkwood, R.N., Lapwood, K.R., Smith, W.C. \& Anderson, 1.L. (1984a) Plasma concentrations of LH, prolactin, oestradiol-17 and progesterone in sows weaned after lactation for 10 or 35 days. J. Reprod. Fert. 70, 95-102.

Kirkwood, R.N., Lapwood, K.R., Smith, W.C., Moller, K. \& Garrick. D.J. (1984b) Effects of oestradiol benzoate treatment on the reproductive performance and endocrine status of sows after lactations of 10 or 35 days. J. Reprod. Fert. 72, 329-337.

Legault, C. \& Dagorn, J. (1973) Incidence de l'age a la premiere mise-bas sur la productivitie de la truie. Journées Rech. porc. en France pp. 227-237.

Libal, G.W. \& Wahlstrom, R.C. (1977) Effect of level of feeding during lactation on sow and pig performance. J. Anim. Sci. 41, 1524-1545.

Lodge, G.A. \& Hardy, B. (1968) Influence of nutrition during oestrus on ovulation rate in the sow. $J$. Reprod. Fert. 15, 329-332.

MacLean, C.W. (1969) Observations on non-infectious infertility in sows. Vet. Rec. 85, 675-682.

MacPherson, R.M., Elsley, F.W.H. \& Smart, R.I. (1969) The influence of dietary protein intake during lactation on the reproductive performance of sows. Anim. Prod. 11, 443-451.

MacPherson, R.M., Hovell, F.D.DeB. \& Jones, A.S. (1977) Performance of sows first mated at puberty or second or third oestrus, and carcass assessment of once bred gilts. Anim. Prod. 24, 333-342.

McGillivray, J.J., Nalbandov, A.V., Jensen, A.H., Norton, H.W., Harmon, B.G. \& Becker, D.E. (1964) Effect of source and level of protein on early reproductive performance in gilts. J. Anim. Sci. 23, 1214, Abstr.

Moser, B.D. \& Lewis, A.J. (1980) Adding fat to sow diets-an update. Feedstuffs 59, 36-62.

National Research Council (1959, 1964, 1968, 1973, 1979) Nutrient requirements of swine. National Academy of Science, Washington D.C.

Nelssen, J.L., Lewis, A.J., Peo, E.R., Kittok, R.J., Kinder, J.E., Zimmerman, D.R., Johnson, R.K. \& Crenshaw, J.D. (1984) Effect of dietary energy intake of sows during lactation on their postweaning hormone profiles. J. Anim. Sci. 59 (Suppl. 1), p. 247, Abstr.

O'Grady, J.F. (1980) Energy and protein nutrition of the sow. In Recent Advances in Animal Nutrision, pp. 121-131. Ed. W. Haresign. Butterworths, London.

O'Grady, J.F., Elsley, F.W.H., MacPherson, R.M. \& McDonald, I. (1973) The response of lactating sows and their litters to different dietary energy allowances. 1. Milk yield and composition, reproductive performance of sows and growth rate of litters. Anim. Prod. 17, 65-74.

Pike, I.H. \& Boaz, T.G. (1972) The effect of condition at service and plane of nutrition in early pregnancy in the sow. I. Uterine and extra uterine changes. Anim. Prod. 15, 147-155.

Reese, D.E., Moser, B.D., Peo. E.R., Lewis, A.J., Zimmerman, D.R., Kinder, J.E. \& Stroup, W.W. (1982a) Influence of energy intake during lactation on the interval from weaning to first estrus in sows. $J$. Anim. Sci. 55, 590-598.

Reese, D.E., Moser, B.D., Peo, E.R., Lewis, A.J., Zimmerman, D.R., Kinder, J.E. \& Stroup. W.W. (I982b) Influence of energy intake during lactation and subsequent gestation, on lactation and postweaning performance of sows. J. Anim. Sci. 55. 867-872.

Reese, D.E., Peo, E.R. \& Lewis, A.J. (1984) Relationship of lactation energy intake and occurrence of postweaning estrus to body and backfat composition in sows. J. Anim. Sci. 58, 1236-1244.

Rutter, L.M. \& Randel, R.D. (1984) Postpartum nutrient intake and body composition: effect on pituitary function and onset of estrus in beef cattle. J. Anim. Sci. 58, 265-274.

Salmon-Legagneur, E. \& Rerat, A. (1962) Nutrition of the sow during pregnancy. In Nutrition of Pigs and Poultry, pp. 207-237. Eds. J. T. Morgan \& D. Lewis. Butterworths, London.

Seerley, R.W. (1984) The use of fats in sow diets. In Fats in Animal Nusrition, pp. 333-352. Ed. J. Wiseman. Butterworths, London.

Seerley, R.W. \& Ewan, R.C. (1983) An overvicw of energy utilization in swine nutrition. J. Anim. Sci. 57, $300-314$

Speer, V.C. (1982) Feed restrictions and sow response. In Symposium on Management of Food Producing Animals, vol. 2, pp. 554-572. Ed. W. Woods. Purdue University, West Lafayette.

Svajgr, A.J., Hammell, D.L., DeGeeter, M.J. Hays, V.W., Cromwell, G.L. \& Dutt, R.H. (1972) Reproductive performance of sows on a protein restricted diet. J. Reprod. Fert. 30, 455-458.

Toplis, P., Ginesi, M.F.J. \& Wrathall, A.E. (1983) The influence of high food levels in early pregnancy on embryo survival in multiparous sows. Anim. Prod. 37, 45-48.

Tribble, L.F. \& Orr, D.E. (1982) Effect of feeding level after weaning on reproduction in sows. J. Anim. Sci. $55,608-612$.

Wadman. J.B. \& Holness, D.H. (1973) Cytological changes observed in pituitary cells of the indigenous sows (Sus Scrofa Domesticus) resulting from experimental underfeeding. Rhod. J. agric. Res. 11, 35-39.

Wahlstrom, R.C. \& Libal, G.W. (1977) Effect of dictary protein during growth and gestation on development and reproductive performance of gilts. J. Anim. Sci. 45, 94-99.

Whittemore, C.T. (1983) Development of recommended energy and protein allowances for young pigs. Agric. Systemis 11, 159-186.

Whittemore, C.T., Franklin, M.F. \& Pearce, B.S. (1980) Fat changes in breeding sows. Anim. Prod. 31, 183-190.

Whittemore, C.T., Taylor, A.G., Hillyer, G.M., Wilson, D. \& Stamataris, C. (1984) Influence of body fat stores on reproductive performance of sows. Anim. Prod. 38, 527, Abstr.

Zimmerman, D.R., Peo, E.R. \& Hudman, D.B. (1967) Plant vs. animal protein as a source of supplemental protein for the gilt. J. Anim. Sci. 26, 514-517. 